\title{
Analisis Manajemen Organisasi dan Sumber Daya Manusia (Studi Kasus pada Industri Velg Mobil)
}

\author{
Tatbita Titin Suhariyanto $^{1}$, Raden Achmad Chairdino Leuveano ${ }^{2}$, Suhariyanto ${ }^{3}$ \\ ${ }^{1}$ Program Studi Teknik Industri \\ Fakultas Teknologi Industri, Universitas Ahmad Dahlan, Daerah Istimewa Yogyakarta, Indonesia 55191 \\ ${ }^{2}$ Department of Mechanical and Materials Engineering \\ Fakulti Kejuruteraan dan Alam Bina, Universiti Kebangsaan Malaysia, Bangi UKM, Malaysia 43600 \\ ${ }^{3}$ Departemen Teknik Mesin Industri \\ Fakultas Vokasi, Institut Teknologi Sepuluh Nopember Surabaya, Indonesia 60111 \\ email : tatbita.suhariyanto@,ie,uad.ac.id \\ doi: https://doi.org/10.31315/opsi.v13i1.3470
}

Received: 12 th June 2020; Revised: $22^{\text {nd }}$ June 2020; Accepted: $25^{\text {th }}$ June 2020;

Available online: $30^{\text {th }}$ June 2020; Published regularly: June 2020

\begin{abstract}
Due to the importance of organizational management and human resources (HR) in the company, this study intends to analyze several aspects related to these two things, such as internal and external conditions of the company, existing business strategies, existing organizational structures, and job descriptions in a position. This research chooses one of the long-standing car alloy wheels industry. By conducting SWOT method, observations and interviews, there are some conclusions about the company's existing conditions and the formulation of new business strategies. The recommendations proposed in this study include to optimize opportunities and to strengthen the internal factors of the company (SO strategy), to design a new organizational structure with the addition of several specific positions, and to design HR strategies to be more competent.
\end{abstract}

Keywords: Organizational Management; Human Resource Management; SWOT; Job Analysis; Organizational structure; Human Resources Strategy

\begin{abstract}
ABSTRAK
Begitu pentingnya manajemen organisasi dan sumber daya manusia (SDM) dalam perusahaan, penelitian ini ingin menganalisis beberapa aspek terkait dua hal tersebut, seperti kondisi internal dan eksternal perusahaan, strategi bisnis saat ini, struktur organisasi saat ini, dan deskripsi pekerjaan pada sebuah jabatan. Penelitian ini memilih salah satu industri velg mobil yang sudah berdiri sejak lama. Dengan menggunakan metode SWOT (Strengths, Weaknesses, Opportunities, and Threats), observasi, dan wawancara, didapatkan beberapa kesimpulan tentang kondisi saat ini perusahaan dan perumusan strategi bisnis yang baru. Rekomendasi yang diusulkan dalam penelitian ini antara lain pemanfaatan peluang dan memperkuat faktor internal yang dimiliki perusahaan (strategi Strengths-Opportunities), perancangan struktur organisasi baru dengan penambahan beberapa jabatan spesifik, dan perancangan strategi SDM agar lebih kompeten.
\end{abstract}

Keywords: Manajemen Organisasi; Manajemen Sumber Daya Manusia; SWOT; Strategi Bisnis; Analisis Jabatan; Struktur Organisasi; Strategi Sumber Daya Manusia

\section{PENDAHULUAN}

Strategi merupakan kunci sukses dalam suatu perusahaan dan langkah untuk mencapai tujuan jangka panjang dan pendek dari suatu perusahaan. Dalam menentukan strategi, pengelolaan sumber daya adalah poin penting untuk mencapai tujuan dari perusahaan tersebut.

Strategi bisnis merupakan korelasi antara kapabilitas internal perusahaan (visi, misi, dan sasaran) dengan keadaan eksternal (keadaan pasar dan sumber daya). Jadi, strategi suatu perusahaan haruslah mencangkup objektif (apa yang harus diraih) dari perusahaan tersebut dan rancangan kegiatan. Terdapat tiga unsur dasar dalam pengembangan strategi perusahaan yaitu strategi bisnis, struktur organisasi ,dan manajemen sumber daya manusia (MSDM). Hubungan tesebut dapat digambarkan pada Gambar 1. 


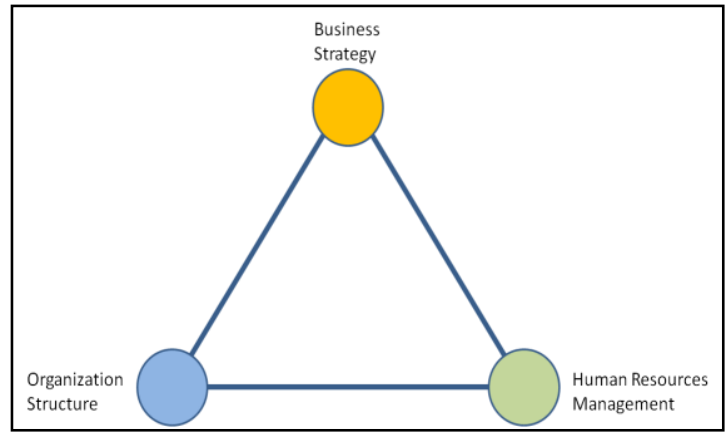

Gambar 1. Hubungan antara Strategi Bisnis, Struktur Organisasi, dan Manajemen SDM (Fomburn, Tichy, \& Devanna, 1984)

Ketiga unsur dari Gambar 1 mempunyai peranan penting dalam pengembangan perusahaan, baik jangka pendek maupun jangka panjang. Tiap-tiap poin ini akan saling berhubungan satu sama lain. Sebagai contoh, suatu perusahaan memiliki strategi bisnis cost leadership namun struktur organisasi yang dibuat bersifat operational excellence sehingga terdapat ketidakcocokan dari strategi dan langkah mencapai strategi tersebut.

MSDM juga memegang peran penting dalam menjalankan strategi perusahan. MSDM merupakan pengalokasian sumber daya secara tepat guna sesuai bisnis strategi yang telah ditentukan. Apabila strategi bisnis telah ditentukan, namun sumber daya manusia tidak dirancang dan dikelola dengan baik, maka akan menyebabkan ketimpangan dalam perusahaan. Jadi, strategi bisnis, struktur organisasi, dan MSDM harus dijalankan dengan selaras untuk mencapai tujuan perusahaan.

Oleh karena itu, penelitian ini bertujuan untuk menganalisis manajemen organisasi dan sumber daya manusia (SDM) pada sebuah perusahaan manufaktur velg mobil. Penelitian diperlukan untuk menyelesaikan permasalahan terkait dengan strategi pengembangan perusahaan. Beberapa permasalahan yang ingin diselesaikan dalam penelitian adalah:

1. Bagaimana kondisi internal dan eksternal pada perusahaan amatan?

2. Bagaimana strategi saat ini dan perumusan strategi baru yang sesuai dengan visi dan misi serta kondisi internal eksternal?

3. Bagaimana struktur organisasi yang selaras dengan strategi perusahaan amatan?

4. Bagaimana perancangan deskripsi pekerjaan (job description), spesifikasi pekerjaan (job specification), dan kompetensi (job competence) pada suatu jabatan dalam perusahaan amatan?

\section{Bagaimana menurunkan strategi perusahaan ke dalam strategi SDM?}

\section{METODE}

Penelitian ini diawali dengan identifikasi masalah yakni bagaimana perusahaan menentukan strategi bisnis yang menunjang keberlangsungan perusahaan. Hal ini terkait pula dengan visi misi perusahaan dan bagaimana perusahaan mampu mengeksplorasi serta mengembangkan SDM sesuai dengan kebutuhan dan standar perusahaan.

Tahap selanjutnya adalah perumusan masalah dan penetapan tujuan. Perumusan masalah ini terkait dengan pertanyaanpertanyaan terkait dengan identifikasi masalah. Kemudian, dilanjutkan dengan mengumpulkan data, baik melalui studi lapangan maupun studi kepustakaan.

Dalam penelitian ini, studi lapangan berupa pengamatan dan wawancara secara langsung dengan salah satu pihak perusahaan yang kompeten di bidang manajemen organisasi dan sumber daya manusia (MOSDM). Teknik wawancara yang digunakan adalah focus group discussion (FGD) dengan salah satu pemegang jabatan di perusahaan. FGD dilakukan secara sistematis dan terarah dengan mengacu pada kuesioner analisis jabatan. FGD ini terdiri dari tiga orang interviewer dan satu orang interviewee. Selanjutnya, studi kepustakaan dilakukan dengan mencari data tahunan perusahaan, seperti kapasitas produksi dan profil perusahaan.

Dari studi lapangan dan studi pustaka ini, didapatkan data perusahaan yang berhubungan dengan strategi dan MOSDM yakni visi misi, strategi dan obyektif perusahaan, struktur organisasi perusahaan, dan lain sebagainya. Langkah selanjutnya adalah pengolahan data yang meliputi perumusan strategi, analisis kondisi internal dan eksternal, perumusan strategi berdasarkan Peta Ancaman, Peluang, Kelemahan, dan Kekuatan (Threats, Opportunities, Weaknesses, and Strengths/ TOWS Map), serta penetapan strategi berdasarkan Tracy Wieserma.

Sebagai langkah yang penting dalam perumusan strategi, penentuan bobot dan penilaian dalam Matriks TOWS juga dilakukan dengan mewawancarai salah satu pihak perusahaan yang memahami kondisi internal dan eksternal perusahaan tersebut. Narasumber diminta untuk memberikan bobot dan penilaian 
untuk setiap faktor, kemudian diolah menggunakan software Analytical Hierarchy Process (AHP) "Expert Choice".

Selanjutnya, strategic alignment disusun dengan melakukan penyesuaian struktur organisasi saat ini dengan visi, misi dan strategi perusahaan, serta penyusunan struktur organisasi yang baru. Dari penyusunan struktur organisasi yang baru, dilanjutkan dengan penyusunan strategic alignment untuk MSDM.

Langkah seterusnya adalah melakukan analisis dan evaluasi pekerjaan (job analysis and evaluation) melalui pengamatan langsung dan wawancara dengan pihak pengembangan sumber daya manusia (Human Resource Development/HRD). Hasil pengamatan dan wawancara ini digunakan untuk penyusunan deskripsi pekerjaan baru yang lebih sesuai. Dari seluruh rangkaian kegiatan tersebut, dilanjutkan dengan intepretasi dan analisis, serta penarikan kesimpulan dan saran perbaikan. Secara ringkas, diagram alur penelitian ini dapat dilihat pada Gambar 2.



Gambar 2. Diagram Alir Metode Penelitian

\section{HASIL DAN PEMBAHASAN}

3.1 Analisis Kondisi Internal dan Eksternal Perusahaan Amatan

Analisis Kekuatan, Kelemahan, Peluang dan Ancaman (Strengths, Weaknesses, Opprtunities, and Threats/SWOT) memiliki banyak manfaat karena dapat membantu melihat persoalan dari empat sisi sekaligus, serta menjadi dasar sebuah analisis (Hardiyanto, Soejanto, \& Berlianty, 2018). Analisis SWOT mampu memberikan hasil berupa analisis yang cukup tajam sehingga mampu memberikan rekomendasi untuk mempertahankan kekuatan sekaligus memaksimalkan peluang, sambil meminimalkan kekurangan dan juga menghindari ancaman (Rahayu, Rachawati, \& Sutrisno, 2018)

Sebelum melakukan analisis SWOT, langkah pertama adalah mengidentifikasi visi dan misi perusahan, serta aspek internal dan eksternal perusahaan. Berdasarkan hasil wawancara dengan pihak perusahaan yang memahami kondisi internal dan eksternal perusahaan dengan baik, visi dari perusahaan ini adalah "ingin menjadi produsen velg kelas dunia", sedangkan misinya adalah "memproduksi velg sesuai selera pasar internasioal dengan jalur distribusi di seluruh dunia".

Untuk analisis SWOT, pernyataan dari narasumber tersebut diterjemahkan dan diklasifikasikan sesuai dengan faktornya. Sebagai contoh, narasumber mengatakan bahwa memiliki model yang beragam, namun tidak mempunyai kantor cabang di Eropa. Kedua hal tersebut dapat diklasifikasikan sebagai kekuatan dan kelemahan. Semua faktor yang ada pada SWOT adalah pernyataan implisit dari narasumber yang diterjemahkan menjadi faktorfaktor dalam SWOT.

Secara rinci, kondisi internal dan eksternal perusahaan dapat dilihat pada Tabel 1 dan 2 . Kemudian, kondisi-kondisi tersebut dijelaskan lebih detail dan diklasifikasikan ke dalam tabel analisis SWOT, seperti yang disajikan pada Tabel 3, 4, 5, dan 6. Berdasarkan analisis SWOT, kondisi internal lebih didominasi oleh faktor kekuatan (strengths) daripada kelemahan (weaknesses). Hal ini wajar mengingat perusahaan ini sudah berdiri cukup lama, sehingga unit usahanya sudah bisa dikatakan stabil. Pada kondisi eksternal, peluang (opportunities) juga lebih mendominasi dibandingkan ancaman (threats) yang ada. 
Tabel 1. Kondisi Internal dan Eksternal Perusahaan Amatan

\begin{tabular}{cll}
\hline No & \multicolumn{1}{c}{ Aspek } & \\
\hline 1 & SDM & Jarang terjadi konflik internal \\
2 & Produk & Memiliki model velg yang beragam \\
& & Memiliki harga produk yang kompetitif \\
3 & Pengelolaan hubungan & Memiliki kemampuan untuk mengakomodasi permintaan model konsumen \\
& dengan customer & Memiliki customer loyal (60\% dari total customer) \\
& Proses operasional & Mampu melakukan maintenance yang baik \\
& & Memiliki prosentase reject sedikit \\
& & Memiliki waktu produksi lebih panjang (24 jam sehari) \\
& & Hanya mengandalkan pameran dan internet untuk memasarkan produk \\
& & Pengelolaan hubungan \\
dengan pihak luar & Memiliki hubungan kerjasama dengan merk-merk terkenal \\
& & Distributor resmi sedikit (hanya 1 di Amerika) \\
& & Hanya mengandalkan supplier dari luar negeri dan kurang memaksimalkan \\
& & supplier lokal \\
& & Hanya terpaku pada pasar Eropa, Amerika dan Timur Tengah \\
& Belum populer di Indonesia (hanya 2\% di Indonesia) \\
\hline
\end{tabular}

Tabel 2. Kondisi Eksternal Perusahaan Amatan

\begin{tabular}{|c|c|c|}
\hline No & Aspek & Kondisi \\
\hline 1 & Calon pendatang & $\begin{array}{l}\text { Kompetitor lokal sulit untuk menyayaigi perusahaan, namun } \\
\text { kompetitor luar mudah muncul dikarenakan persaingan global } \\
\text { (misalnya Tiongkok) }\end{array}$ \\
\hline 2 & Pelanggan & Memiliki peluang untuk memenuhi kebutuhan pasar velg di Indonesia \\
\hline & & Berpeluang melakukan perluasan pasar di luar negeri \\
\hline 3 & Supplier & Harga bahan baku semakin meningkat \\
\hline 4 & Produk pengganti & $\begin{array}{l}\text { Banyakya perusahaan lain yang menghasilkan produk sejenis } \\
\text { mengakibatkan mudahnya pelanggan berpaling ke produk yang lain }\end{array}$ \\
\hline 5 & Kompetitor industri & $\begin{array}{l}\text { Adanya kompetitor/pesaing yang cukup berat, terutama dari } \\
\text { Tiongkok karena cukup banyak }\end{array}$ \\
\hline
\end{tabular}

Tabel 3. Faktor Kekuatan Perusahaan Amatan

\section{Kekuatan (Strengths)}

S1 Memiliki model velg yang beragam

S2 Memiliki hubungan yang baik dengan customer

S3 Memiliki hubungan kerjasama dengan merk-merk terkenal

S4 Jarang terjadi konflik internal

S5 Memiliki waktu produksi lebih panjang (24 jam sehari)

S6 Memiliki harga produk yang kompetitif

S7 Memiliki daerah pendistribusian produk di negara-negara maju

S8 Memiliki prosentase reject sedikit

S9 Memiliki kemampuan untuk mengakomodasi permintaan model konsumen

S10 Memiliki standar sertifikasi ISO dan sertifikasi dari Jerman

S11 Mampu melakukan perawatan yang baik

S12 Memiliki customer loyal (60\% dari total customer)
Tabel 4. Faktor Kelemahan Perusahaan Amatan

\section{Kelemahan (Weaknesses)}

W1 Belum populer di Indonesia (hanya 2\% di Indonesia)

W2 Distributor resmi sedikit (hanya 1 di Amerika)

W3 Hanya mengandalkan pameran dan internet untuk memasarkan produk

W4 Hanya mengandalkan supplier dari luar negeri dan kurang memaksimalkan supplier lokal

W5 Hanya terpaku pada pasar Eropa, Amerika, dan Timur Tengah 
Tabel 5. Faktor Peluang Perusahaan Amatan Peluang (Opportunities)

\begin{tabular}{ll}
\hline O1 & $\begin{array}{l}\text { Memiliki peluang untuk memenuhi } \\
\text { kebutuhan pasar velg di Indonesia }\end{array}$ \\
O2 & $\begin{array}{l}\text { Berpeluang untuk menjalin kerjasama } \\
\text { dengan pabrik mobil di dunia }\end{array}$ \\
O3 & $\begin{array}{l}\text { Berpeluang untuk memaksimalkan iklan } \\
\text { dan promosi }\end{array}$ \\
O4 & $\begin{array}{l}\text { Berpeluang untuk membuka lebih } \\
\text { banyak distributor resmi baik di } \\
\text { Indonesia atau di negara lain }\end{array}$ \\
O5 & $\begin{array}{l}\text { Berpotensi untuk membuat velg } \\
\text { kendaraan lain (motor) } \\
\text { Berpeluang melakukan perluasan pasar } \\
\text { di luar negeri }\end{array}$ \\
\hline
\end{tabular}

Tabel 6. Faktor Ancaman Perusahaan Amatan

\begin{tabular}{cl}
\hline & \multicolumn{1}{c}{ Ancaman (Threats) } \\
\hline T1 & $\begin{array}{l}\text { Isu lingkungan yang tidak } \\
\text { memperbolehkan proses produksi yang } \\
\text { mengakibatkan pencemaran lingkungan }\end{array}$ \\
T2 & Isu perubahan ekonomi dunia \\
T3 & $\begin{array}{l}\text { Adanya kompetitor/pesaing yang cukup } \\
\text { berat terutama dari China karena cukup }\end{array}$ \\
& banyak \\
T4 & $\begin{array}{l}\text { Harga bahan baku yang semakin } \\
\text { meningkat }\end{array}$ \\
T5 & Adanya fluktuasi nilai tukar asing \\
\hline
\end{tabular}

\subsection{Perumusan Strategi}

Perumusan strategi dilakukan dengan memperhatikan aspek visi misi serta SWOT perusahaan. Dalam penelitian ini, perumusan strategi dilakukan dengan menganalisis SWOT perusahaan menjadi Matriks TOWS (lihat Lampiran 1). Selanjutnya, setiap faktor SWOT disusun dan dihitung menggunakan Matriks IFE dan EFE. Kemudian, hasil selisih kedua matriks digambarkan dalam bentuk Peta SWOT.

\subsubsection{Penyusunan Matriks IFE dan EFE}

Menurut Zulkarnain, Wahyuningtyas, \& Putranto (2017), analisis kekuatan eksternal mempengaruhi jenis produk yang dikembangkan, karakteristik segmentasi pasar, strategi penentuan posisi, jenis layanan yang ditawarkan, dan pilihan bisnis yang ingin dijual. Sedangkan analisis kekuatan internal berperan sebagai upaya penentuan kemampuan organisasi dalam operasi dan mencapai kinerja.

Matriks Evaluasi Faktor Internal (Internal Factor Evaluation/IFE) merupakan tabel yang menunjukkan evaluasi pada kondisi internal perusahaan. Kondisi internal ini berdasarkan kekuatan dan kelemahan yang telah dijelaskan sebelumnya (lihat Sub Bab 3.1). Dari Matriks
IFE ini, dapat diketahui seberapa besar pengaruh dari masing-masing faktor kekuatan dan kelemahan dari perusahaan tersebut. Besar pengaruh dapat dilihat pada besarnya hasil perkalian antara bobot (weight) dan penilaian (rating). Langkah dalam menyusun IFE matriks ini adalah sebagai berikut:

- Tulis semua faktor kekuatan dan kelemahan

- Beri bobot dan penilaian pada setiap faktor

- Kalikan bobot dengan penilaian

- Jumlahkan hasil kali bobot dengan penilaian

Bobot merupakan nilai yang menunjukkan seberapa besar pengaruh antara keadaan satu dengan keadaan lainnya dalam memengaruhi tiap faktor SWOT. Sedangkan penilaian adalah besarnya nilai terhadap kondisi saat ini perusahaan. Total nilai semua bobot dalam tiap faktor SWOT haruslah 1. Nilai tertinggi hasil kali bobot dengan penilaian adalah 4 , terendah adalah 1 dan rata-ratanya adalah 2.5. Untuk penilaian, angka 1 menunjukkan prioritas pengaruh paling rendah dan 4 adalah yang paling tinggi.

Perhitungan bobot dan penilaian Matriks Evaluasi Faktor Eksternal (External Factor Evaluation/EFE) pada hakekatnya adalah sama dengan Matriks IFE. Namun, faktor yang dinilai adalah faktor peluang dan ancaman. Secara rinci, perhitungan kedua matriks ini dapat dilihat pada Tabel 7 dan 8 .

Tabel 7. Matriks IFE

\begin{tabular}{|c|c|c|c|c|}
\hline & Kekuatan & Bobot & Nilai & Total \\
\hline S1 & $\begin{array}{l}\text { Model yang } \\
\text { beragam }\end{array}$ & 0.106 & 3 & 0.318 \\
\hline S2 & $\begin{array}{l}\text { Menjalin } \\
\text { hubungan yang } \\
\text { baik dengan } \\
\text { pelanggan }\end{array}$ & 0.161 & 4 & 0.644 \\
\hline S3 & $\begin{array}{l}\text { Kerjasama dengan } \\
\text { merk-merk } \\
\text { terkenal }\end{array}$ & 0.236 & 3 & 0.708 \\
\hline S4 & $\begin{array}{l}\text { Jarang terjadi } \\
\text { konflik internal }\end{array}$ & 0.021 & 2 & 0.042 \\
\hline S5 & $\begin{array}{l}\text { Waktu produksi } \\
\text { lebih panjang ( } 24 \\
\text { jam sehari) }\end{array}$ & 0.033 & 3 & 0.099 \\
\hline S6 & $\begin{array}{l}\text { Harga produk } \\
\text { yang kompetitif }\end{array}$ & 0.064 & 4 & 0.256 \\
\hline S7 & $\begin{array}{l}\text { Pendistribusian } \\
\text { produk di negara- } \\
\text { negara maju }\end{array}$ & 0.043 & 3 & 0.129 \\
\hline S8 & Reject sedikit & 0.105 & 3 & 0.315 \\
\hline S9 & $\begin{array}{l}\text { Mampu } \\
\text { mengakomodasi } \\
\text { permintaan model } \\
\text { konsumen }\end{array}$ & 0.091 & 3 & 0.273 \\
\hline
\end{tabular}




\begin{tabular}{|c|c|c|c|c|}
\hline S10 & $\begin{array}{l}\text { Memiliki standar } \\
\text { sertifikasi ISO dan } \\
\text { sertifikasi dari } \\
\text { Jerman }\end{array}$ & 0.021 & 2 & 0.042 \\
\hline S11 & $\begin{array}{l}\text { Melakukan } \\
\text { maintenance yang } \\
\text { baik }\end{array}$ & 0.033 & 3 & 0.099 \\
\hline S12 & $\begin{array}{l}\text { Memiliki customer } \\
\text { loyal ( } 60 \% \text { dari } \\
\text { total customer) }\end{array}$ & 0.090 & 3 & 0.27 \\
\hline & Total & 1.00 & 36.00 & 3.20 \\
\hline & Kelemahan & Bobot & Nilai & Total \\
\hline W1 & $\begin{array}{l}\text { Belum } \\
\text { populer di } \\
\text { Indonesia } \\
\text { (hanya 2\% di } \\
\text { Indonesia) }\end{array}$ & 0.109 & 4 & 0.436 \\
\hline W2 & $\begin{array}{l}\text { Distributor } \\
\text { resmi sedikit } \\
\text { (hanya } 1 \mathrm{di} \\
\text { Amerika) }\end{array}$ & 0.198 & 3 & 0.594 \\
\hline W3 & $\begin{array}{l}\text { Hanya } \\
\text { mengandalkan } \\
\text { pameran dan } \\
\text { internet untuk } \\
\text { memasarkan } \\
\text { produk }\end{array}$ & 0.379 & 2 & 0.758 \\
\hline W4 & $\begin{array}{l}\text { Lokasi dan } \\
\text { fasilitas } \\
\text { pabrik yang } \\
\text { kurang } \\
\text { terawat }\end{array}$ & 0.050 & 2 & 0.1 \\
\hline W5 & $\begin{array}{l}\text { Hanya } \\
\text { terpaku pada } \\
\text { pasar Eropa, } \\
\text { Amerika dan } \\
\text { Timur Tengah }\end{array}$ & 0.264 & 2 & 0.528 \\
\hline Total & & 1 & 13 & 2.416 \\
\hline \multicolumn{2}{|c|}{ Selisih } & & & 0.78 \\
\hline
\end{tabular}

\begin{tabular}{|c|c|c|c|c|}
\hline T1 & $\begin{array}{l}\text { Isu lingkungan } \\
\text { yang tidak } \\
\text { memperbolehka } \\
\text { n proses } \\
\text { produksi yang } \\
\text { mengakibatkan } \\
\text { pencemaran } \\
\text { lingkungan }\end{array}$ & 0.309 & 3 & 0.927 \\
\hline $\mathbf{T} 2$ & $\begin{array}{l}\text { Isu perubahan } \\
\text { ekonomi dunia }\end{array}$ & 0.285 & 3 & 0.855 \\
\hline T3 & $\begin{array}{l}\text { Adanya } \\
\text { kompetitor/pesai } \\
\text { ng yang cukup } \\
\text { berat terutama } \\
\text { dari China } \\
\text { (karena cukup } \\
\text { banyak) }\end{array}$ & 0.092 & 2 & 0.184 \\
\hline T4 & $\begin{array}{l}\text { Harga bahan } \\
\text { baku yang } \\
\text { semakin } \\
\text { meningkat }\end{array}$ & 0.064 & 3 & 0.192 \\
\hline T5 & $\begin{array}{l}\text { Adanya fluktuasi } \\
\text { nilai tukar asing }\end{array}$ & 0.250 & 3 & 0.75 \\
\hline Total & & 1 & 14 & 2.908 \\
\hline Selisih & & & & 0.59 \\
\hline
\end{tabular}

. Sebagai contoh, faktor kekuatan dengan kalimat "model yang beragam" memiliki bobot 0.106 , artinya "model yang beragam" ini mempengaruhi kondisi perusahaan sebesar $10.6 \%$. Kemudian, penilaian pada faktor kekuatan "model yang beragam" memiliki penilaian sebesar 3. Sesuai dengan skala Likert, maka angka 3 ini memiliki arti "penting" (skala Likert, 1 adalah tidak penting, 2 adalah cukup penting, 3 adalah penting dan 4 adalah sangat penting). Alasan mengapa diberi bobot seperti

Tabel 8. Matriks EFE

\begin{tabular}{|c|c|c|c|c|}
\hline & Peluang & Bobot & Nilai & Total \\
\hline O1 & $\begin{array}{l}\text { Pemenuhan } \\
\text { kebutuhan pasar } \\
\text { Indonesia }\end{array}$ & 0.154 & 3 & 0.462 \\
\hline $\mathrm{O} 2$ & $\begin{array}{l}\text { Menjalin } \\
\text { kerjasama } \\
\text { dengan pabrik } \\
\text { mobil }\end{array}$ & 0.390 & 4 & 1.56 \\
\hline $\mathbf{O 3}$ & $\begin{array}{l}\text { Maksimalkan } \\
\text { iklan dan } \\
\text { promosi }\end{array}$ & 0.154 & 4 & 0.616 \\
\hline O4 & $\begin{array}{l}\text { Membuka lebih } \\
\text { banyak } \\
\text { distributor resmi }\end{array}$ & 0.190 & 3 & 0.57 \\
\hline 05 & $\begin{array}{l}\text { Membuat velg } \\
\text { kendaraan lain } \\
\text { (motor) }\end{array}$ & 0.046 & 2 & 0.092 \\
\hline O6 & $\begin{array}{l}\text { Perluasan pasar } \\
\text { di luar negeri }\end{array}$ & 0.067 & 3 & 0.201 \\
\hline & Total & 1.00 & 19.00 & 3.50 \\
\hline & Ancaman & Bobot & Nilai & Total \\
\hline
\end{tabular}
itu dikarenakan "model yang beragam" memiliki tingkat pengaruh cukup signifikan terhadap perusahaan. Model yang beragam menuntut perusahaan untuk mengeksplorasi ide dan mengembangkan model baru setiap periode tertentu. "Model yang beragam" juga memegang peranan cukup penting karena ketika model yang ditawarkan tidak beragam (monoton) maka perusahaan bisa kehilangan konsumen.

Pemberian bobot dan penilaian ini berlaku untuk semua faktor. Untuk poin terendah, misalkan faktor kelemahan dengan kalimat "lokasi dan fasilitas yang kurang terawat". Faktor ini memiliki bobot sebesar 0.05 dan penilaian sebesar 2. Artinya, faktor ini tidak begitu berpengaruh pada proses produksi velg dan kurang penting peranannya dalam perusahaan. Menurut narasumber, hal yang menjadi fokus utama perusahaan adalah mendapatkan profit, bukan kebersihan lingkungan (secondary focus). Secara ringkas, pembobotan terbesar akan diberikan pada faktor 
yang berpotensi memberikan pengaruh dan memiliki peran penting paling besar pada perusahaan. Begitu juga sebaliknya.

\subsubsection{Penyusunan Peta SWOT dan Matriks TOWS}

Titik pada peta SWOT didapat dari selisih nilai antara kekuatan dengan kelemahan (untuk sumbu $\mathrm{x}$ ) dan selisih nilai antara peluang dengan ancaman (untuk sumbu y). Bila kedua nilai positif, maka letak titik pada peta SWOT adalah di kuadran I, bila sumbu x negatif dan sumbu y positif maka titik ada di kuadran II, dan seterusnya.

Pada kasus ini, total nilai faktor kekuatan sebesar 3.2 dan total nilai faktor kelemahan sebesar 2.416 sehingga selisih keduanya adalah 0.78 (positif). Selanjutnya, total nilai faktor peluang sebesar 3.5 dan total nilai faktor ancaman sebesar 2.908 sehingga selisih keduanya adalah 0.59 (positif). Karena kedua selisih nilai adalah positif maka letak kedua titik ada pada kuadran I (lihat Gambar 3), yaitu pemanfaatan peluang dan memperkuat faktor internal yang dimiliki perusahaan (strategi Strengths-Opportunities/strategi SO).

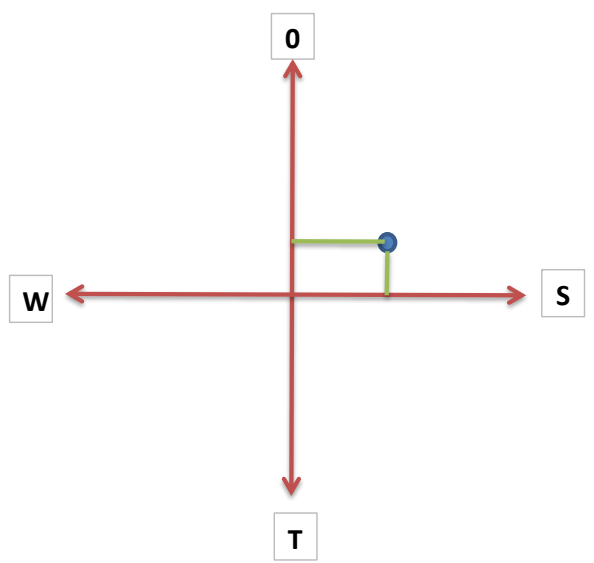

Gambar 3. Peta SWOT

Alasan mengapa perusahaan ada pada titik ini karena perusahaan ini sudah berdiri cukup lama sehingga memiliki faktor kekuatan yang tinggi dengan faktor kelemahan yang cukup rendah. Perusahaan sudah mampu mengatasi persoalan mendasar internal, seperti efisiensi proses, produktivitas, dan lain sebagainya.

Untuk faktor eksternal, karena perusahaan ini hanya memenuhi pasar mancanegara, maka peluang untuk memenuhi pasar Indonesia masih terbuka. Hal inilah yang menjadi peluang utama dalam pengembangan perusahaan ke depannya.
Untuk faktor ancaman, perusahaan velg hanya terkonsentrasi pada UU lingkungan, sehingga kedepannya adalah menemukan cara produksi yang tidak mencemari lingkungan lebih parah. Namun dari segi ekonomi, faktor peluang masih lebih dominan dibandingkan faktor ancaman yang ada. Itulah alasan mengapa kedua nilai positif pada peta SWOT.

Seperti yang telah dijelaskan sebelumnya, karena selisih SW dan OT adalah positif, maka strategi yang diambil adalah strategi SO yang terletak pada kuadran I di Peta SWOT. Setelah mengetahui posisi titik pada Peta SWOT, maka selanjutnya menilik kembali pada Matriks TOWS yang sudah dibuat (lihat Lampiran 1).

Berdasarkan Matriks TOWS, didapatkan hasil bahwa strategi yang digunakan adalah strategi SO. Jumlah keseluruhan strategi SO ada enam strategi. Cara mendapatkan strategi dari Matriks TOWS adalah sebagai berikut:

- Dengan mengggunakan S2, S12, O1 dan O3, maka perusahaan ini dapat menerapkan strategi untuk menjaring pelanggan setia dari Indonesia karena perusahaan ini memiliki pelanggan yang sedikit dari dalam negeri. Penguatan konsumen dalam negeri bisa dijadikan prospek bagus ketika terjadi gejolak ekonomi atau politik di luar negeri yang menghambat terjualnya produk.

- Dengan menggunakan S1 dan O2, maka didapatkan strategi SO2 yakni menjalin kerjasama dengan produsen mobil dan rumah modifikasi di Indonesia.

- Dengan menggunakan S9, S7, S10, S3, dan O4 serta O6, maka didapatkan strategi $\mathrm{SO} 3$ yakni membuka distributor resmi baik di Indonesia maupun negara lain khususnya Eropa dan Timur Tengah untuk lebih menjangkau konsumen.

- Dengan menggunakan S1, S6 dan O3, maka perusahaan dapat menerapkan strategi $\mathrm{SO} 4$ yakni memaksimalkan pemasaran dengan membuat merek sendiri.

- Dengan menggunakan S1, S5, S6, S9 dan O1, maka dapat dijalankan strategi pemenuhan permintaan konsumen Indonesia dengan mengandalkan model dan kualitas produk yang sesuai dengan ekspektasi konsumen. (strategi SO5)

- Dengan menggunakan S1, S5, S6, S9, S10 dan O5 serta O3, maka didapatkan strategi SO6 yakni strategi pembuatan velg motor yang didukung dengan promosi yang efektif untuk meningkatkan penjualan. Artinya, ada 
integrasi antara produksi dengan promosi karena promosi diperlukan untuk mendongkrak nilai jual sehingga lebih mudah dikenal dan dijangkau konsumen.

\subsection{Analisis Jabatan}

Analisis jabatan dilakukan dengan mewawancarai salah satu pemegang jabatan di perusahaan menggunakan kuesioner analisis jabatan. Kuesioner ini merupakan kuesioner standar dalam MSDM yang mengacu pada Dessler (2006). Jabatan yang dipilih untuk menjawab kuesioner ini adalah Manajer Personalia dan Urusan Umum (Personalia and General Affair/P\&GA). Jabatan ini dipilih karena mampu memberikan gambaran mengenai kondisi MSDM dalam perusahaan (Syahidah \& Trisyulianti, 2020). Dalam hal ini, peran manajer adalah pelaksana unit kerja. Sedangkan unit kerja adalah orientasi tugas kelompok dalam suatu organisasi yang mencakup manajer dan bawahan atau staf (Rifa'i \& Fadhli, 2013).

MSDM merupakan bagian sangat penting dalam sebuah perusahaan karena hal tersebut harus selaras dengan struktur organisasi dan strategi bisnis perusahaan. Dengan memilih jabatan manajer bidang P\&GA, dapat diketahui keselarasan antara MSDM dengan struktur organisasi dan strategi bisnis.

Langkah pertama yang dilakukan adalah merancang kuesioner analisis jabatan untuk menggali informasi tentang deskripsi dan spesifikasi jabatan tersebut (lihat Lampiran 2). Kemudian, hasil dari kuesioner analisis jabatan direkap ke dalam sebuah formulir deskripsi pekerjaan (lihat Lampiran 3). Dari formulir tersebut, dapat diperoleh penjelasan tentang pekerjaan yang dilakukan oleh jabatan tersebut, pengalaman dan pengetahuan yang disyaratkan, tanggung jawab yang diemban, dan wewenang yang berhak dilakukan. Informasi dari formulir tersebut dapat dirumuskan menjadi deskripsi, spesifikasi, dan kompetensi pekerjaan dari jabatan manajer P\&GA.

\subsubsection{Kuesioner Analisis Jabatan}

Selama wawancara, ada beberapa pertanyaan yang diajukan dalam bentuk kuisioner analisis jabatan. Kuesioner ini adalah kuisioner awal yang digunakan untuk melakukan analisis pekerjaan. Hasil dari wawancara ini digunakan untuk menyusun deskripsi dan spesifikasi pekerjaan. Berikut ini adalah rekap hasil wawancara dari kuesioner analisis jabatan.

1. Apakah tujuan keseluruhan dari pekerjaan Anda?

Jawab: Mengelola SDM, mengelola keperluan peningkatan produktifitas dalam hal efisiensi dan penganggaran (budgeting), melakukan pengembangan kemampuan SDM dengan pelatihan, dan membuat situasi kerja kondusif dengan pemberian penghargaan dan sanksi.

2. Aktivitas apa yang anda lakukan sebagai kewajiban?

Jawab: Pelatihan, penilaian prestasi, konseling.

3. Bagaimana jenis dan luasnya wewenang yang Anda terima?

Jawab: Dibatasi oleh peraturan perindustrian, termasuk pemberian surat peringatan, dan promosi.

4. Apakah kewajiban pekerjaan harian, periodik, dan pada interval yang tidak beraturan yang harus Anda lakukan?

Jawab: Pekerjaan harian yaitu pengontrolan situasi kerja dan segala hal yang berhubungan dengan karyawan. Pekerjaan periodik yaitu mengevaluasi tingkat kehadiran karyawan, mengevaluasi faktor keselamatan dan kesehatan kerja (K3) perusahaan, dan evaluasi hasil produktivitas (per 3 bulan). Pekerjaan pada interval tidak beraturan yaitu mengatur kunjungan dari institusi pemerintahan dan lingkungan.

5. Apakah pemegang jabatan melakukan kewajiban yang Anda anggap tidak perlu?

Jawab: Tidak, karena bagian personalia (dalam hal ini P\&GA) adalah departemen yang bersifat umum dan mencangkup dari hal yang paling kecil misal menu makan karyawan dan hal yang bersifat personal misal keluhan dan saran dari karyawan.

6. Apakah pemegang jabatan melakukan kewajiban yang saat ini tidak disertakan dalam deskripsi pekerjaan?

Jawab: Tidak, sama alasannya dengan jawaban di nomor 5. Bagian personalia merupakan departemen umum yang jelas ranah dan cakupannya.

7. Apa pendidikan terakhir untuk pekerjaan anda?

Jawab: Pendidikan pascasarjana atau gelar tinggi

8. Berapa lama pengalaman yang dibutuhkan untuk pekerjaan Anda? 
Jawab: 10 tahun, diawali dari staf umum lalu supervisor dan saat ini menjabat manager P\&GA.

9. Dimanakah lokasi pekerjaan Anda? Jawab: Di dalam ruangan hingga lantai produksi.

10. Bagaimana kondisi lingkungan yang diterima oleh Anda selama bekerja?

Jawab: Kondisi lingkungan yang stabil dan cenderung tidak berbahaya.

11. Bagaimana kondisi kesehatan dan keamanan yang diterima Anda selama bekerja?

Jawab: Kondisi cenderung aman dan tidak berbahaya.

12. Peralatan apa yang Anda gunakan dalam pekerjaan?

Jawab: Komputer dan telepon pintar.

13. Apakah standar kerja sudah dibuat oleh perusahaan?

Jawab: Tidak ada, hanya sebatas mengelola agenda yang telah dibuat dan melalui media kendali yang ada.

14. Bagaimana kepribadian yang dibutuhkan dalam pekerjaan Anda?

Jawab: Berfikir secara jernih, menyenangkan, dan mengerti sedikit hukum.

15. Apakah ada kondisi pengecualian dalam melakukan pekerjaan Anda?

Jawab: Tidak ada

16. Bagaimana cara penyelesaian yang Anda lakukan dalam pekerjaan?

Jawab: Penyelesaian dilakukan berdasarkan agenda kerja harian.

17. Seberapa luas dampak dari kesalahan pada pekerjaan ini? Siapa yang terkena dampaknya?

Jawab: Kesalahan dalam memutuskan akan berdampak pada seluruh sumber daya manusia yang ada di perusahaan, seperti manajer dan karyawan.

18. Pekerjaan apa yang Anda harapkan untuk dipromosikan?

Jawab: Tidak ada jabatan yang spesifik, hanya ingin membuat situasi menjadi lebih baik.

\subsubsection{Analisis Deskripsi dan Spesifikasi Jabatan}

Berdasarkan hasil wawancara kuesioner analisis jabatan, jabatan ini memiliki atasan Direktur Manajer, dimana manager P\&GA harus memberikan laporan kepada Direktur Manajer tersebut. Tujuan dari pekerjaan ini adalah mengelola sumber daya manusia yang ada di perusahaan untuk keperluan peningkatan produktivitas dan pengembangan kemampuan SDM melaui pelatihan internal maupun eksternal. Pelatihan pengembangan juga sering dilakukan secara langsung ketika sedang bekerja di lantai produksi atau kantor. Selain itu, pekerjaan ini berperan untuk membuat situasi kerja yang kondusif dengan pemberian penghargaan and sanksi pada pekerja untuk menjaga stabilitas kinerja perusahaan.

Pengalaman yang dibutuhkan untuk melakukan pekerjaan ini kurang lebih sepuluh tahun pengalaman. Latar belakang pendidikan yang sesuai untuk pekerjaan ini adalah psikologi dasar, hukum, dan teknik. Minimal persyaratan pendidikan adalah tingkat pasca sarjana atau gelar tinggi. Pekerjaan ini membutuhkan karakter pribadi yang dapat berpikir secara jernih, menyenangkan, dan memiliki rasa humor.

Tanggung jawab penting dari pekerjaan ini meliputi seluruh bidang yang ada di struktur organisasi. Hal ini dikarenakan objektif dari pekerjaan ini adalah pengembangan SDM. Kewajiban harian yang dilakukan oleh jabatan ini adalah pengontrolan situasi kerja dan karyawan. Pengontrolan ini meliputi pengelolaan jam kerja dan jam istirahat karyawan, menu makan karyawan, dan lain lain. Kewajiban periodik yang dilakukan per tiga bulan adalah pemantauan terhadap tingkat kehadiran karyawan dan K3 (Keselamatan dan Kesehatan Kerja). Pemantauan terhadap karyawan ini akan memberikan sistem penilaian terhadap kinerja karyawan. Karyawan yang mampu bekerja dengan baik akan diberikan penghargaan. Begitu pula sebaliknya, karyawan yang tidak bekerja dengan baik dan melanggar aturan akan diberikan sanksi. Penilaian prestasi ini dilakukan menggunakan media kendali yang meliputi target kehadiran dan produksi tiap karyawan.

Pekerjaan ini juga bertanggung jawab untuk menjaga motivasi pekerja agar performansi kerja selalu dipertahankan dan ditingkatkan (Hamsinah, Sjahrudin, \& Gani, 2017). Selain itu, peningkatan kompetensi melalui pelatihan dan peningkatan perilaku melalui konseling juga merupakan tanggung jawab yang penting dari jabatan ini. Keadaan psikologis karyawan menjadi perhatian utama bagi pekerjaan ini. Selain itu, kewajiban yang dilakukan pada interval tidak beraturan adalah 
penyambutan tamu dari instansi pemerintah, lingkungan hidup, maupun instansi lain.

Wewenang dari jabatan ini adalah pemberian gaji, pemberian Surat Peringatan (SP), pengelolaan kenaikan jabatan (promosi), dan pemberian pensiun. Luasnya wewenang ini dibatasi oleh peraturan perundang - undangan pemerintah dan KKB (batasan antara pengusaha dengan pekerja).

Secara ringkas, perumusan deskripsi pekerjaan pada jabatan ini adalah:

1. Mengelola SDM untuk keperluan peningkatan produktivitas dengan melakukan efisiensi proses.

2. Mengelola SDM dengan pengembangan kemampuan dan kompetensi melalui pelatihan internal dan eksternal.

3. Melakukan penilaian terhadap kinerja pegawai guna pemberian penghargaan dan sanksi.

4. Melakukan pengontrolan terhadap tingkat kehadiran karyawan, keselamatan dan kesehatan kerja karyawan, dan hasil produktivitas per tiga bulanan.

5. Bertanggung jawab pada kunjungan yang dilakukan dari pihak eksternal seperti lingkungan hidup dan instansi pemerintah.

6. Bertanggung jawab pada proses rekruitmen, pengembangan karyawan, penaikan jabatan, pemberian gaji, pemberian SP, dan perlakuan pada karyawan pensiun.

Spesifikasi pekerjaan yang dibutuhkan bagi pekerjaan ini adalah:

1. Memiliki tingkat pendidikan minimal pendidikan pasca sarjana atau gelar tinggi (MM).

2. Memiliki pengalaman bekerja kurang lebih 10 tahun.

Kompetensi pekerjaan yang dibutuhkan bagi pekerjaan ini adalah:

1. Memiliki dasar pengetahuan mengenai psikologi, hukum, dan teknik.

2. Mampu berpikir secara jernih, memiliki sifat yang menyenangkan, dan humoris.

3.3.3 Kesesuaian deskripsi, spesifikasi, dan kompetensi pekerjaan dengan strategi bisnis perusahaan

Jika melihat deskripsi, spesifikasi, dan kompetensi saat ini, maka hal ini telah mendukung strategi SO yang telah dirumuskan. Deskripsi pekerjaan sudah terdefinisi dan terjadwal dengan jelas berupa agenda kerja harian. Namun, hal ini dapat diperbaiki dengan implementasi SOP yang baik pada pelaksanaan pekerjaan agar dapat mencapai visi perusahaan, yaitu menjadi penghasil velg kelas dunia.

Dalam keterkaintannya dengan strategi perusahaan, manajer P\&GA memiliki deskripsi pekerjaan yang penting dalam pengembangan kompetensi karyawan yang selaras dengan strategi perusahaan. Hal ini juga ditunjang dengan spesifikasi pekerjaan manajer $\mathrm{P} \& \mathrm{GA}$ yang harus memiliki pengalaman bekerja selama sepuluh tahun. Dengan pengalaman bekerja yang cukup lama, maka diharapkan seorang manajer P\&GA mampu melakukan pengembangan kompetensi karyawan sesuai dengan harapan perusahaan. Selain spesifikasi pekerjaan, kompetensi pekerjaan manajer P\&GA yang harus memiliki pengetahuan dalam bidang psikologi juga mendukung strategi perusahaan dalam menumbuhkan budaya perusahaan yang kondusif dalam bekerja (Almasri, 2016).

\subsection{Penyusunan Struktur Organisasi Baru}

Pada tahapan ini, struktur organisasi yang baru disusun berdasarkan keterkaitan antara struktur organisasi saat ini dengan visi misi dan strategi perusahaan. Struktur organisasi yang baru ini harus menyesuaikan dengan strategi yang telah dirumuskan sebelumnya.

Pada struktur organisasi yang baru (lihat Gambar 4), ada beberapa elemen yang ditambahkan. Hal ini sesuai dengan fungsi pengorganisasian agar setiap elemen dapat menjalankan fungsinya masing-masing (Rachman, 2015). Dalam struktur organisasi yang lama, tiap departemen berdiri sendiri dan langsung dibawahi oleh dewan direksi. Hal ini dapat mengakibatkan pengontrolan yang tidak menyeluruh bagi tiap departemen, sehingga disusunlah penambahan seorang direktur manajer untuk mengkoordinasikan beberapa departemen yang sejenis. Direktur manajer yang ditambahkan adalah bagian yang membawahi bidang geografis, finansial, P\&GA, dan produksi. 


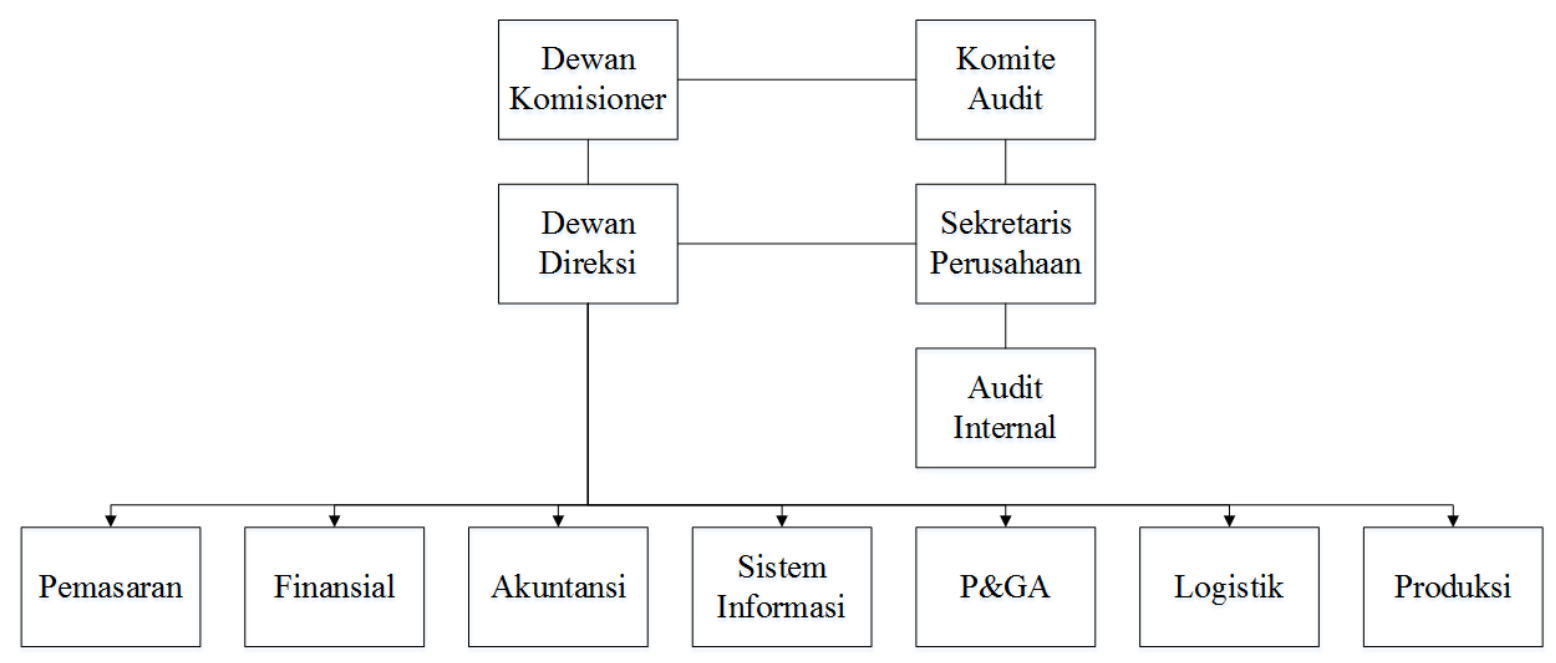

(a)

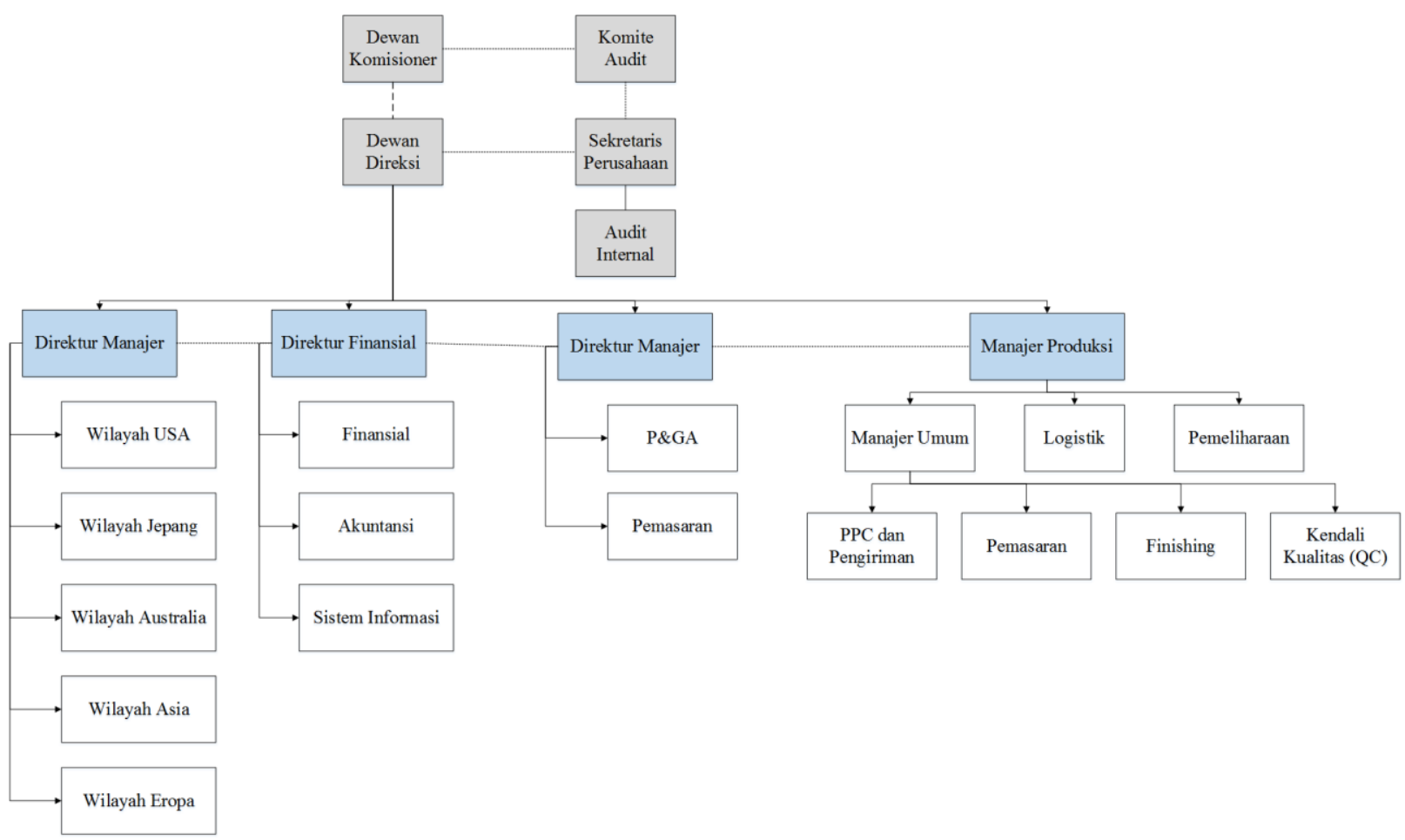

(b)

Gambar 4. (a) Struktur Organisasi Saat Ini; (b) Struktur Organisasi Baru

Selain penambahan direktur manajer, bentuk hubungan antar elemen juga diperjelas dengan adanya macam - macam garis yang berbeda. Garis - garis yang ditambahkan dalam struktur organisasi baru adalah garis kontrol, instruktif, dan instruktif koordinatif.

Struktur organisasi perusahaan saat ini memiliki delapan departemen yang langsung dibawahi oleh dewan direksi. Dalam memimpin jalannya kegiatan usaha, direksi dibantu oleh sekretaris perusahaan yang mewakili perusahaan dalam berkominikasi dengan semua pihak pasar modal. Sekreatris perusahaan juga membantu direksi dalam melaksanakan rapat umum tahunan maupun rapat umum luar biasa dengan pemegang saham perusahaan. Dewan komisaris merupakan pemegang saham perusahaan yang selalu memantau hasil kinerja direksi dengan dibantu oleh komite audit. Hubungan koordinasi seperti ini tidak tergambar jelas dalam struktur organisasi yang ada saat ini. Koordinasi dalam struktur hanya berupa garis - 
garis yang sama antar elemen. Hal ini memungkinkan adanya kerancuan dalam menjalankan deskripsi pekerjaan ataupun alur informasi yang tidak selaras. Selain kurang jelasnya garis koordinasi, rentang kendali dari direksi juga tidak ideal karena harus mengontrol delapan departemen. Hal ini memungkinkan adanya kelalaian dalam pengontrolan sehingga kinerja yang dihasilkan tidak maksimal.

Dengan menganalisis struktur organisasi saat ini, dapat dihasilkan sebuah rekomendasi struktur organisasi yang baru dengan mengatasi permasalahan yang timbul dari struktur organisasi yang lama. Perbedaan struktur organisasi lama dengan baru adalah pada bagian penjelasan garis, penambahan direktur manajer, dan penambahan departemen.

Garis hubungan koordinasi pada struktur organisasi lama yang kurang jelas digambarkan dalam bentuk garis yang berbeda yang memiliki arti berbeda pada tiap macam garis. Hubungan antara dewan komisionaris dengan komite audit yang saling berkoordinasi untuk mengawasi kinerja direksi digambarkan dengan garis koordinasi yang berbentuk garis titik titik menyambung. Begitu pula dengan bentuk hubungan koordinasi antara direksi dengan sekretaris perusahaan yang saling berkoordinasi dalam menjalankan aktivitas perusahaan.

Garis koordinasi juga diperjelas dalam hubungan tiap departemen, dimana tiap departemen harus bekerja selaras dengan departemen lain. Hal ini merupakan bentuk integrasi dari perusahaan. Tiap departemen harus memiliki informasi tentang departemen lain agar tidak terjadi kesalahpahaman yang menghambat kemajuan perusahaan.

Selain garis koordinasi yang berbentuk titik-titik menyambung, garis hubungan kendali antara dewan komisioner dengan dewan direksi juga diperjelas dengan garis putus - putus. Hal ini berarti bahwa dewan komisioner selalu memantau kinerja dewan direksi dalam mengelola perusahaan agar sejalan dengan target dan rencana pertumbuhan yang telah ditetapkan.

Garis hubungan instruktif koordinatif juga diperjelas dalam hubungan antara dewan direksi dengan direktur manajer tiap bidang dan hubungan antara manager director dengan tiap departemen. Dewan direksi memberikan instruksi kepada masing - masing manager director untuk menjalankan aktivitas agar sesuai dengan target dan rencana pertumbuhan yang telah ditetapkan. Dewan direksi juga harus selalu berkoordinasi dengan direktur manajer agar tidak ada informasi yang hilang ataupun hal lain yang menghambat pertumbuhan perseroanperusahaan. Direktur manajer juga memberikan instruksi kepada tiap departemen mengenai target dan rencana perusahaan serta saling mengkoordinasikan antar tiap departemen yang dibawahinya.

Penambahan direktur manajer berfungsi untuk membawahi beberapa departemen yang sejenis agar dewan direksi tidak memiliki rentang kendali yang terlalu banyak. Selain itu, direktur manajer juga memiliki peran untuk mengkoordinasikan aktivitas dalam departemen dan antar departemen. Alur informasi dan koordinasi antar departemen merupakan hal penting yang harus dilakukan oleh direktur manajer. Beberapa departemen juga ditambahkan seperti departemen yang mengatur di tiap wilayah benua, departemen pemeliharaan, departemen logistik, dan manajer umum yang membawahi departemen pengendalian dan perencanaan produksi, pengiriman, permesinan, dan kendali kualitas.

Strategi SO yang telah dirumuskan adalah penjaringan pelanggan loyal, menjalin kerjasama dengan produsen mobil dan rumahrumah modifikasi di Indonesia, membuka distributor lebih banyak di luar negeri, lebih gencar memasarkan dengan merk sendiri, memenuhi permintaan model customer, dan membuat velg motor dengan promosi yang efektif melalui berbagai media komunikasi. Hal ini telah sesuai dengan struktur organisasi baru yang telah dirumuskan. Penambahan departemen yang menangani masalah di tiap wilayah benua akan lebih memberi fokus kerja yang maksimal dalam pendistribusian produk, terutama di Indonesia. Hal ini dikarenakan kantor pendistibusian produk hanya berada di Amerika saja. Media pemasaran juga akan lebih maksimal dengan penanganan yang dilakukan oleh direktur manajer yang membawahi departemen pemasaran karena selama ini departemen ini dibawahi secara langsung oleh dewan direksi yang juga membawahi banyak departemen lain.

\subsection{Penyusunan MSDM}

Pengembangan strategi SDM (human resource/HR) disusun karena SDM merupakan komponen penting dalam perusahaan (Priyono, 2008). MSDM memiliki dua fungsi dasar, yaitu fungsi perencanaan dan fungsi operasional (Tim Dosen Mata Kuliah Manajemen Sumber Daya 
Manusia, 2009). Perumusan strategi SDM dilakukan dengan langkah - langkah dasar seperti diagram alir pada Gambar 5.
- Menjadi penghubung dalam pengaturan SDM perusahaan dengan strategi melalui kartu penilaian SDM dan pelatihan

Gambar 5. Perumusan Strategi SDM

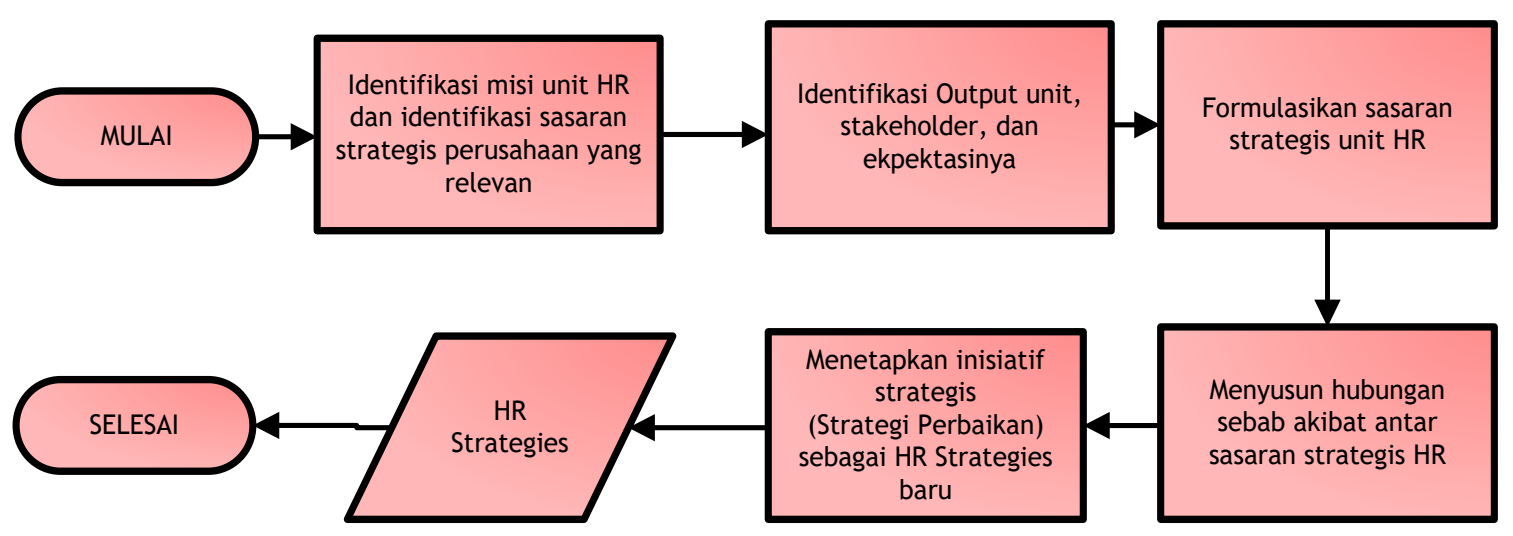

Langkah pertama adalah identifikasi misi unit SDM dan sasaran strategis perusahaan yang relevan. Setelah itu mengidentifikasi output unit, pemangku kepentingan, dan ekspektasinya. Kemudian, memformulasikan sasaran strategis unit SDM. Tahap keempat adalah menyususn hubungan sebab akibat antar sasaran strategis SDM. Pada tahap kelima, merancang inisiatif strategis (strategi perbaikan) sehingga mendapatkan strategi SDM baru. Secara rinci, langkah-langkah pengembangan strategi SDM pada subbab selanjutnya.

\subsubsection{Identifikasi misi unit SDM dan sasaran} strategis perusahaan yang relevan.

Sasaran strategi unit SDM saat ini masih dalam ranah yang tidak terlalu menyeluruh, artinya unit SDM di perusahaan ini masih belum secara optimal membina kompetensi para pekerjanya. Dilihat dari visi misi ekspektasi, unit SDM memiliki banyak kekurangan dalam pengaplikasian tujuannya. Unit SDM di perusahaan ini masih berada di kuadran management of employee contribution yaitu peran unit SDM yang masih belum menjadikan fokus masa utama. Sasaran unit SDM yang bisa diapliksikan berdasarkan visi misi ekspektasi adalah:

- Melakukan pelatihan dan pengembangan secara berkala yang bertujuan untuk meningkatkan kompetensi karyawan.

- Mengelola kemampuan manajerial karyawan agar mampu meningkatkan proses kerja organisasi secara efisien, contohnya melalui sistem informasi SDM. strategi bisnis.

- Melakukan perubahan sistem manajemen kerja secara menyeluruh saat terjadi perubahan lingkungan (pasar dan permintaan).

Dari visi misi ekspektasi dan sasaran strategi dari unit SDM terdapat hubungan dengan visi misi dan strategi baru dari perusahaan. Dari subbab sebelumnnya bisa diambil kesimpulan bahwa perusahaan ini menggunakan strategi SO yaitu strategi yang memaksimalkan faktor kekuatan dengan memanfaatkan faktor peluang yang muncul. Unit SDM sebagai unsur penting dalam kerangka bisnis memiliki peranan yang saling berhubungan dengan strategi ekspektasi dari perusahaan. Hal ini akan dijelaskan pada subbab selanjutnya.

\subsubsection{Identifikasi output unit SDM, pemangku kepentingan, dan ekspektasinya \\ Tahap selanjutnya adalah identifikasi} pemangku kepentingan (stakeholder) dari unit SDM. Pemangku kepentingan ini terdiri dari dua jenis yaitu pemangku kepentingan utama (primary stakeholder) dan pemangku kepentingan sekunder (secondary stakeholder).

Pemangku kepentingan utama adalah bagian dari perusahaan yang menggunakan SDM di perusahaan tersebut, sedangkan pemangku kepentingan sekunder adalah input dari SDM yang akan dikelola oleh unit. Secara rinci, pemangku kepentingan dari perusahaan ini adalah sebagai berikut:

- Pemangku kepentingan utama

- Semua karyawan perusahaan 
- Semua pekerja kontrak (kondisional)

- Semua unit di lingkungan perusahaan

- Pemangku kepentingan sekunder

- Universitas kerja sama

- Lulusan sarjana atau pasca sarjana

Setelah melihat visi misi, strategi, dan pemangku kepentingan unit SDM, maka dapat dirumuskan output dari unit SDM untuk perusahaan ini adalah:

1. Terbentuk pekerja dan karyawan yang berkualitas dari segi produktifitas dan manajemen pekerjaan

2. Terlaksananya proses rekruitmen yang jelas dan berkualitas

3. Penjadwalan jam kerja yang efektif dan efisien

4. Terciptanya pelayanan yang baik antara karyawan, pekerja, dan konsumen

Langkah selanjutnya adalah mengidentifikasi ekspektasi konsumen dari unit SDM. Secara detail, matriks output dan ekspektasi pemangku kepentingan dapat dilihat pada Lampiran 4.

\subsubsection{Penyusunan strategi SDM}

Melihat dari matriks output kondisi saat ini dan ekspektasi dari unit SDM, terdapat gap antara kedua kondisi tersebut. Hal inilah yang menjadi tujuan dibuatnya strategi SDM yang baru.

Berdasarkan misi unit SDM, strategi perusahaan, dan ekspektasi pemangku kepentingan, diperoleh strategi SDM yang baru yaitu perencanaan pelatihan rutin untuk mendukung kegiatan operasional, perencanaan pelatihan terkait dengan masalah finansial dan pemasaran, penyusunan konsep dan penetapan jenjang karir, pemetaan dan penempatan staf sesuai kompetensi serta pengembangan Sistem Informasi SDM (Human Resources Information System/HRIS).

Dari hasil penyusunan strategi unit SDM, terdapat hubungkan dengan pemilihan strategi perusahaan yang baru yaitu strategi berbasis SO (strengths-opportunities), yaitu:

- Strategi perusahaan yang bertujuan untuk penguatan konsumen dan penambahan target pasar sesuai dengan strategi unit SDM yaitu perencanaan pelatihan terkait pelayanan pelanggan, finansial, dan pemasaran.

- Peningkatan kualitas produk yang harus bisa mengikuti fleksibilitas pasar sesuai dengan strategi unit SDM yaitu pelatihan rutin yang diadakan perusahaan sehinngga kompetensi dan kualitas sumber daya manusia yang terus bertambah sehingga mempengaruhi performa kerja.

Hasil penyusunan strategi SDM harus dapat menjawab gap dari kondisi saat ini dan ekspektasi. Strategi SDM yang dirumuskan dalam penelitian ini adalah sebagai berikut:

- Perencanaan pelatihan rutin untuk mendukung operasional perusahaan.

Dengan dilaksanakannya pelatihan rutin, maka diharapkan kualitas sumber daya manusia yang ada dalam perusahaan akan semakin meningkat. Kegiatan pelatihan ini berupa pelatihan yang menunjang kegiatan operasional yang bermanfaat untuk meningkatkan performa kerja staf.

- Perencanaan pelatihan terkait finansial dan pemasaran untuk mendukung keseluruhan proses bisnis perusahaan.

Pelatihan ini diharapkan dapat meningkatkan kualitas SDM dalam bidang finansial dan pemasaran agar keuangan perusahaan dapat dikelola dengan efisien, transparan, dan dapat dipertanggungjawabkan.

- Penyusunan konsep dan penetapan jenjang karir.

Strategi ini bertujuan untuk menentukan deskripsi pekerjaan masing-masing staf sehingga dapat menunjang tercapainya visi dan misi perusahaan.

- Pemetaan dan penempatan staf sesuai kompetensi.

Tujuan adanya pemetaan dan penempatan staf sesuai kompetensinya adalah agar para staf dapat bekerja semaksimal mungkin. Hal ini disebabkan oleh perbedaan kompetensi masing-masing staf sehingga staf harus ditempatkan secara tepat berdasarkan kompetensi masing-masing.

- Mengembangkan HRIS

Strategi ini bertujuan untuk mengatur sistem informasi dari setiap SDM yang ada agar segala informasi dapat diketahui oleh setiap karyawan perusahaan. Dengan tersalurnya informasi dengan merata, maka visi misi perusahaan dapat tercapai dengan mudah.

Strategi SDM yang berkaitan dengan deskripsi pekerjaan adalah adanya struktur dan budaya organisasi yang kondusif untuk menjalankan aktivitas perusahaan. Hal ini ditunjang dengan deskripsi pekerjaan dari jabatan P\&GA yang berkewajiban untuk menciptakan suasana kondusif di dalam perusahaan (Niam \& Syah, 2019). Selain itu, 
strategi SDM juga berkaitan dengan deskripsi pekerjaan manajer P\&GA dalam pengembangan kompetensi karyawan. Strategi SDM juga berkaitan dengan kompetensi pekerjaan manajer P\&GA yaitu seleksi dan rekruitmen, kebijakan jenjang karir, dan terbentuknya komunikasi yang baik antar pegawai (Ariani, Suseno, \& Sutarno, 2019). Hal ini ditunjang dengan kompetensi manajer P\&GA yang harus memiliki kemampuan berkomunikasi yang baik dan berkepribadian yang menyenangkan.

\section{KESIMPULAN}

Kondisi internal dari perusahaan ini adalah jarang terjadi konflik internal, memiliki model velg yang beragam, memiliki harga produk yang kompetitif, memiliki kemampuan untuk mengakomodasi permintaan konsumen, memiliki pelanggan yang loyal, mampu melakukan pemeliharaan dengan baik, memiliki prosentase penolakan (reject) sedikit, dan memiliki waktu produksi lebih panjang. Selain itu, perusahaan ini hanya mengandalkan pameran dan internet dalam memasarkan produk, namun memiliki hubungan kerjasama dengan merek-merek terkenal dan memiiki daerah pendistribusian produk di negara maju. Sayangnya, distributor resmi hanya sedikit, hanya mengandalkan suplier luar negeri. Perusahaan ini hanya terpaku pada pasar Eropa, dan belum populer di Indonesia.

Kondisi eksternal dari perusahaan ini adalah adanya kompetitor lokal sulit untuk menyayaigi perusahaan, namun kompetitor luar mudah muncul dikarenakan persaingan global, seperti Tiongkok. Perusahaan ini memiliki peluang untuk memenuhi kebutuhan pasar velg di Indonesia dan berpeluang melakukan perluasan pasar di luar negeri. Namun, perusahaan ini juga mendapatkan ancaman dari eksternal seperti harga bahan baku semakin meningkat, banyakya perusahaan lain yang menghasilkan produk sejenis, dan adanya kompetitor/pesaing yang cukup berat, terutama dari Tiongkok karena cukup banyak.

Setelah melakukan analisis strategi saat ini, dapat dirumuskan strategi baru yang sesuai visi, misi, dan kondisi internal dan eksternal organisasi amatan, yaitu penjaringan pelanggan loyal, menjalin kerjasama dengan produsen mobil dan rumah rumah modifikasi di Indonesia, membuka distributor lebih banyak di luar negeri dan lebih gencar memasarkan dengan merk sendiri. Perusahaan juga diharapkan dapat memenuhi permintaan model pelanggan, dan membuat velg motor dengan promosi yang efektif melalui berbagai media komunikasi.

Struktur organisasi yang baru dirancang selaras dengan strategi perusahaan berupa penambahan departemen yang menangani masalah di tiap wilayah benua. Media pemasaran juga akan lebih maksimal dengan penanganan yang dilakukan oleh direktur manajer yang membawahi departemen pemasaran karena departemen ini masih dibawahi secara langsung oleh dewan direksi yang juga membawahi banyak departemen lain.

Penyusunan deskripsi, spesifikasi, dan kompetensi pekerjaan dilakukan dengan memilih jabatan manajer P\&GA. Penyusunan ini dilakukan dengan teknik wawancara dan kuesioner analisis jabatan.

Untuk mengaplikasikan strategi perusahaan yang baru ke dalam strategi SDM yang baru, perusahaan ini memiliki unit SDM yang disebut departemen P\&GA. Departemen ini awalnya tidak memiliki visi dan misi yang tertulis jelas. Namun, ranah kerja dari depatemen ini sudah jelas. Dengan adanya sasaran strategi perusahaan yang baru, maka unit SDM juga mengalami perubahan, apalagi dengan fungsi unit HR yang saat ini tidak lagi hanya sebatas manajemen karyawan.

Terakhir, pihak perusahaan merasa terbantu dengan hasil analisis dan usulan rekomendasi dalam penelitian ini. Berdasarkan hasil wawancara, perusahaan sedang dalam fase pengembangan pasar yang memerlukan strategi baru. Hal ini tentu sesuai dengan usulan-usulan yang diberikan penelitian ini. Selain MOSDM, penelitian selanjutnya dapat dilakukan dengan menganalisis manajemen pemasaran dan kinerja yang telah dilakukan perusahaan.

\section{UCAPAN TERIMA KASIH}

Penulis mengucapkan terima kasih kepada kedua sahabat yang telah membantu dalam pengerjaan penelitian ini, yaitu Yasminta Kris Widianto dan Angga Ari Prasetio. Selain itu, penulis juga berterima kasih atas kerjasama Laboratorium Perancangan Sistem dan Manajemen Industri Institut Teknologi Sepuluh Nopember Surabaya yang telah memberikan masukan terkait penelitian ini. Penulis juga berterima kasih kepada pihak perusahaan yang sangat kooperatif dalam membantu kami untuk mendapatkan data yang diperlukan. 


\section{DAFTAR PUSTAKA}

Almasri, M. N. (2016). Manajemen Sumber Daya Manusia: Imlementasi Dalam Pendidikan Islam. Kutubkhanah: Jurnal Penelitian Sosial Keagamaan, 19, 133151.

Ariani, R., Suseno, D., \& Sutarno. (2019). Analisis Pengaruh Penempatan Karyawan, Karakteristik Individu, dan Stres Kerja Terhadap Kinerja (Survei pada Karyawan Non PNS RSUD Dr. Harjono S Kabupaten Ponorogo). Jurnal Manajemen Sumber Daya Manusia, $311(2), 300-309$.

Dessler, Gary. (2006). Manajemen Sumber Daya Manusia. Jakarta: Prehallindo.

Hamsinah, Sjahrudin, H., \& Gani, M. (2017). Jurnal organisasi dan manajemen. Jurnal Organisasi Dan Manajemen, 10(1), 6276.

Hardiyanto, A., Soejanto, I., \& Berlianty, I. (2018). Analisis Strategi Pembangunan Desa Wisata Di Sentra Pengrajin Keris. OPSI - Jurnal Optimasi Sistem Industri, $11(1), 1$.

Niam, J., \& Syah, T. Y. R. (2019). Pengaruh Motivasi, Kepemimpinan dan Budaya Organisasi Terhadap Kepuasan Kerja serta Dampaknya pada Kinerja Karyawan. OPSI - Jurnal Optimasi Sistem Industri, $12(2), 89$.

Priyono, M. (2008). Manajemen Sumber Daya Manusia. Sidoarjo: Zifatama Publisher.

Rachman, F. (2015). Manajemen Organisasi Dan Pengorganisasian Dalam Perspektif Al-Quran Dan Hadith. Ulumuna: Jurnal Studi Keislaman, 1(2), 291-323.

Rahayu, S. D., Rachawati, D., \& Sutrisno. (2018). Penentuan Strategi Bersaing Berdasarkan Simulasi Sistem Dinamis. OPSI - Jurnal Optimasi Sistem Industri, 11(1), 58-64.

Rifa'i, M., \& Fadhli, M. (2013). Manajemen Organisasi. (Vol. 53). Citapustaka Media Perintis.

Syahidah, S., \& Trisyulianti, E. (2020). Evaluasi Jabatan Berbasis Eckenrode System pada PT Perkebunan Nusantara VIII. Jurnal Manajemen Dan Organisasi (JMO), 11(1), 46-56.

Tim Dosen Mata Kuliah Manajemen Sumber Daya Manusia. (2009). Buku Ajar Manajemen Sumber Daya Manusia. Surabaya, Indonesia: Universitas Wijaya
Putra.

Zulkarnain, Arif., Wahyuningtias, Dianka., \& Putranto, Trias S. (2017). Analysis of IFE, EFE and QSPM matrix on business development strategy. Proceeding of The 4th Friendly City Conference. October 12th, 2017. Medan. Indonesia. 